\title{
Extraction of saponins and toxicological profile of Teucrium stocksianum boiss extracts collected from District Swat, Pakistan
}

\author{
Syed Muhammad Mukarram Shah ${ }^{1}$, Abdul Sadiq ${ }^{1 *}$, Syed Muhammad Hassan Shah² and Shahzeb Khan ${ }^{1}$
}

\begin{abstract}
Background: The current era is facing challenges in the management of neoplasia and weeds control. The currently available anti-cancer and herbicidal drugs are associated with some serious side effects. Therefore numerous researchers are trying to discover and develop plant based alternative particularly for the rational management of cancer and weed control. Teucrium stocksianum possess antioxidant and analgesic activities. The current study was designed to evaluate crude saponins (CS), methanolic extract and sub-fractions of $T$. stocksianum for cytotoxic and phytotoxic potentials. CS, methanolic extract and sub-fractions were extracted from powdered plant material using different solvents. Cytotoxic potential of the extracts at a dose of 10,100 and $1000 \mu \mathrm{g} / \mathrm{ml}$ were evaluated against Brine shrimp's nauplii. Phytotoxic assay also performed at the same concentration against Lemna minor. Etoposide and Paraquat were used as positive controls in cytotoxic and phytotoxic assays respectively.

Results: The percent yield of crude saponins was (5\%). CS demonstrated tremendous brine shrimp lethality showing $<10 \mu \mathrm{g} / \mathrm{ml} \mathrm{LC}_{50}$. The $n$-hexane (HF) and chloroform fractions (CF) demonstrated excellent cytotoxicity with 80 and $55 \mu \mathrm{g} / \mathrm{ml} \mathrm{LC}$ 50 respectively. Whereas the methanolic extract (TSME), ethyl acetate (EAF) and aqueous fractions (AF) revealed moderate cytotoxicity showing 620,860 and $1000 \mu \mathrm{g} / \mathrm{ml} \mathrm{LC} 50$ values respectively. In phytotoxic assay profound inhibition was displayed by HF $(96.67 \%)$ and TSME $\left(95.56 \%, 30 \mu \mathrm{g} / \mathrm{ml} \mathrm{LC} \mathrm{C}_{50}\right)$ against the growth of Lemna minor at $1000 \mu \mathrm{g} / \mathrm{ml}$ respectively. Both CF and EAF demonstrated profound phytoxicity (93.33\%) respectively at highest concentration $(1000 \mu \mathrm{g} / \mathrm{ml})$, while AF and CS demonstrated weak phytotoxicity with 1350 and $710 \mu \mathrm{g} / \mathrm{ml} \mathrm{LC}_{50}$ values respectively.

Conclusion: Cytotoxicity and phytotoxicity assays indicated that the crude saponins, $n$-hexane and chloroform fractions of T. stocksianum could play a vital role in the treatment of neoplasia and as potential natural herbicides. Therefore these sub-fractions are recommended for further investigation with the aim to isolate novel anti-cancer and herbicidal compounds.
\end{abstract}

Keywords: Saponins, Teucrium stocksianum, Cytotoxicity, Phytotoxicity

\section{Background}

Plants are the natural source of a number of drug molecules [1]. Maximum population of the world depends upon the natural medicines formulated from plant sources. Researchers are trying to explore various types of plants for their potential tendency to treat various challenging diseases. The most prominent disease which demands an urgent attention and rational investigation

\footnotetext{
* Correspondence: sadiquom@yahoo.com

'Department of Pharmacy, University of Malakand, Chakdara, Dir, Pakistan

Full list of author information is available at the end of the article
}

is neoplasia [2]. In addition to the medicinal use of plants, these are one of the major sources of income of utmost world population. To increase the production of crops different strategies are employed, one of the strategies is the use of weed killers [3]. The synthetic herbicidal agents are very much effective to control weeds in variety of crops. Nonetheless, most of them are associated with cumbersome adverse effects [4]. As far as the plant sources are concerned, they are void of these unwanted effects. A number of phytochemicals are famous for certain biological and chemical activities for instance, most of the alkaloids are responsible for antimicrobial activity [5], 
flavonoids and phenols possessing antioxidant activity $[6,7]$. Saponins are group of compounds which have a number of pharmacological activities including antiinflammatory, antioxidant, anticancer, insecticidal, anthelmintic and antimicrobial [8-12].

A range of isolated compounds from plant material contributed a lot in the field of clinical research and therapy [13]. The plants having allelopathic activity helped in the development of safe and potent herbicidal agents which increased the per acre production in agricultural sector [14].

Teucrium stocksianum (Lamiaceae) and various species of the genus Teucrium are ethnomedicinally used as analgesic, antipyretic, anticancer and anthelmintic [15-18]. T. royleanum Wall.ex.Benth (Lamiaceae) possesses strong antimicrobial activity and excellent inhibitor of Acetylcholine esterase and Butyrylcholine esterase $[19,20]$. T. stocksianum is used ethnomedicinally as expectorant, antipyretic, anticancer, anti-malarial, bitter and sore throat [21-23]. The essential oils of T. stocksianum has experimentally been reported as a strong analgesic [24]. Based on the thorough review of the available literature on the folk uses of this plant and the extreme necessity for safe, efficacious and economic anticancer and herbicidal drugs, the present study was designed to evaluate the crude saponins and various other samples of $T$. stocksianum for cytotoxic and phytotoxic activity.

\section{Results}

\section{Crude saponins}

Powdered plant material (20 g) of T. stocksianum yielded about $1 \mathrm{~g}(5 \%)$ of crude saponins.

\section{Brine shrimp cytotoxicity effect}

The cytotoxic potential of CS of T. stocksianum, methanolic extract (TSME) and its sub-fractions against brain shrimps were evaluated at different concentrations as shown in Table 1. CS at a test concentration of 10, 100 and $1000 \mu \mathrm{g} / \mathrm{ml}$ caused, 55.55, 63.33 and $94.44 \%$, cytotoxicity respectively which is prominent compared to the other extracts with $\mathrm{LC}_{50}<10 \mu \mathrm{g} / \mathrm{ml}$ (Table 1). TSME demonstrated $58.88,35.55$ and $18.88 \%$ cytotoxicity at concentrations of 1000,100 and $10 \mu \mathrm{g} / \mathrm{ml}$ with $\mathrm{LC}_{50}$ $620 \mu \mathrm{g} / \mathrm{ml}$. The $n$-hexane fraction has shown a practical cytotoxic effect $(67 \%)$ at $1000 \mu \mathrm{g} / \mathrm{ml}$, and moderate at $100 \mu \mathrm{g} / \mathrm{ml}(42 \%)$ and $10 \mu \mathrm{g} / \mathrm{ml}$ (38\%) lethality with $\mathrm{LC}_{50}$ of $80 \mu \mathrm{g} / \mathrm{ml}$. Chloroform caused 71, 60 and $42 \%$ lethality with $\mathrm{LC}_{50}$ of $55 \mu \mathrm{g} / \mathrm{ml}$, while the ethyl acetate fraction displayed 54, 28 and 16 lethal effect with $\mathrm{LC}_{50}$ $860 \mu \mathrm{g} / \mathrm{ml}$ (Table 1). The aqueous fraction also displayed reasonable cytotoxic potential at all test doses, i.e. 49,27 and $12 \%$ with $\mathrm{LC}_{50} 1000 \mu \mathrm{g} / \mathrm{ml}$. Etoposide was used as standard drug $\left(\mathrm{LC}_{50} 9.8 \mu \mathrm{g} / \mathrm{ml}\right)$.

\section{Phytotoxic effect}

The HF fraction has shown maximum phytotoxic effect as compared to other tested samples of T. stocksianum against Lemna minor as shown in Table 2. HF has shown remarkable potential, $96.67 \pm 1.90,82.23 \pm 2.90$ and $51.10 \pm$ $1.10 \%$ at a concentration of 1000,100 and $10 \mu \mathrm{g} / \mathrm{ml} \mathrm{re-}$ spectively, with $\mathrm{LC}_{50}$ of $9.8 \mu \mathrm{g} / \mathrm{ml}$. TSME at lowest concentration $(10 \mu \mathrm{g} / \mathrm{ml})$ displayed good effect $(27.76 \pm$ 1.90 at $10 \mu \mathrm{g} / \mathrm{ml})$, excellent activity $(71.10 \pm 1.10 \%$ at $100 \mu \mathrm{g} / \mathrm{ml}$ ) and outstanding potential $(95.56 \pm 1.10$ at $1000 \mu \mathrm{g} / \mathrm{ml}$ ), as shown in Table 2. Both CF and EAF have shown significant effect $(93.33 \pm 1.90$ and $93.33 \pm$ 1.10) respectively at highest concentration $(1000 \mu \mathrm{g} / \mathrm{ml})$. At a $100 \mu \mathrm{g} / \mathrm{ml} \mathrm{CF}$ and EAF have shown $56.66 \pm 1.90$ and $63.33 \pm 1.10 \%$ growth inhibitions respectively, while both $\mathrm{AF}$ and CS demonstrated weak phytotoxic potential, with $\mathrm{LC}_{50} 1350$ and $710 \mu \mathrm{g} / \mathrm{ml}$ respectively. Moreover, CF was more potent at lowest concentration $(10 \mu \mathrm{g} / \mathrm{ml})$ as compared to EAF.

\section{Discussions}

Evaluation of plants extract candidly helped in the exploration and isolation of numerous precious compounds which aid a lot in the prevention and treatment of various ailments. As far as the cancer therapy is concerned, a large number of plants are scientifically validated by investigators to cope with this disease [25,26]. Valuable compounds, especially the saponins have also been isolated

Table 1 Concentration dependent cytotoxic potential of crude methanolic extracts of $T$. stocksianum and its sub-fractions against Brine shrimps nauplii

\begin{tabular}{|c|c|c|c|c|}
\hline Samples/Drug & Conc $10 \mu \mathrm{g} / \mathrm{ml}$ & Conc $100 \mu / \mathrm{ml}$ & Conc $1000 \mu / \mathrm{ml}$ & $\mathrm{LC}_{50} \mu / \mathrm{ml}$ \\
\hline Crude saponins & $55.555 \pm 1.112 \%$ & $63.332 \pm 3.337 \%$ & $94.444 \pm 2.943$ & $<10$ \\
\hline Methanolic extract & $18.888 \pm 5.886 \%$ & $35.555 \pm 2.943 \%$ & $58.887 \pm 2.944 \%$ & 620 \\
\hline$n$-hexane fraction & $37.777 \pm 2.943 \%$ & $42.221 \pm 2.943 \%$ & $67.777 \pm 2.224 \%$ & 80 \\
\hline Chloroform fraction & $42.221 \pm 2.943 \%$ & $59.999 \pm 1.926 \%$ & $71.110 \pm 2.943 \%$ & 55 \\
\hline Ethyl acetate fraction & $16.666 \pm 1.926 \%$ & $28.888 \pm 1.112 \%$ & $54.444 \pm 2.943 \%$ & 860 \\
\hline Aqueous fraction & $12.221 \pm 2.943 \%$ & $27.777 \pm 2.943 \%$ & $49.998 \pm 1.926 \%$ & 1000 \\
\hline
\end{tabular}

Conc; concentration. Values are expressed as the mean \pm SEM of three independent observations. Standard drug; Etoposide $L_{50}=9.8 \mu \mathrm{g} / \mathrm{ml}$. 
Table 2 Concentration dependent phytotoxic potential of crude methanolic extracts of $T$. stocksianum and its sub-fractions against Lamna minor

\begin{tabular}{lllll}
\hline Sample & Conc; $\mathbf{1 0 0 0} \boldsymbol{\mu g} / \mathbf{m l}$ & Conc; $\mathbf{1 0 0} \boldsymbol{\mu g} / \mathbf{m l}$ & Conc; $\mathbf{1 0} \boldsymbol{\mu g} / \mathbf{m l}$ & $\mathbf{L C} \mathbf{~} \mathbf{\mu g} / \mathbf{m l}$ \\
\hline Crude saponins & $32.99 \pm 2.502 \%$ & $19.99 \pm 1.925 \%$ & $7.77 \pm 1.113 \%$ & 350 \\
Crude methanolic extract & $95.56 \pm 1.10 \%$ & $71.10 \pm 1.10 \%$ & $27.76 \pm 1.90 \%$ & 9.8 \\
n-hexane fraction & $96.67 \pm 1.90 \%$ & $82.23 \pm 2.90 \%$ & $51.10 \pm 1.10 \%$ & 50 \\
Chloroform fraction & $93.33 \pm 1.90 \%$ & $56.66 \pm 1.90 \%$ & $42.23 \pm 2.90 \%$ & 48 \\
Ethyl acetate fraction & $93.33 \pm 1.10 \%$ & $63.33 \pm 1.10 \%$ & $33.33 \pm 1.90 \%$ & 710 \\
Aqueous fraction & $55.55 \pm 2.223 \%$ & $37.77 \pm 1.113 \%$ & $18.88 \pm 1.113 \%$ & \\
\hline
\end{tabular}

Conc; concentration. Values are expressed as the mean \pm SEM of three independent observations. Standard drug; Paraquat, $\mathrm{LD}_{50}=0.90 \mu \mathrm{g} / \mathrm{ml}$.

and purified from many plants for cancer therapy [27]. The cytotoxic activity performed against brine shrimps demonstrated that $T$. stocksianum contains strong anticancer activity. The saponins showed awesome cytotoxic effect $\left(\mathrm{LC}_{50}<10 \mu \mathrm{g} / \mathrm{ml}\right)$ in this study. The cytotoxic effect of saponins has previously been reported by a number of researchers [8]. Saponins are group of secondary metabolites which have a plethora of pharmacological activities, like anthelmintic [11], insecticidal [10] and antioxidant [9]. The anticancer potential of saponins present in $T$. stocksianum is therefore verified in this activity against brine shrimp, as there is a positive correlation between human nasopharyngeal carcinoma and brine shrimp lethality [17]. The CF $\left(\mathrm{LC}_{50}<55 \mu \mathrm{g} / \mathrm{ml}\right)$ and $\mathrm{HF}\left(\mathrm{LC}_{50}<\right.$ $80 \mu \mathrm{g} / \mathrm{ml}$ ) also revealed high cytotoxic activity which may be due to the presence of high quantity of saponins and other cytotoxic compounds in these fractions.

Various herbicidal agents used against weeds in agricultural crops resulted in numerous adverse effects. To control the adverse effects caused by the synthetic herbicides, a range of natural herbicides have been isolated from plant sources [28]. In the present study the phytotoxicity assay divulged that $T$. stocksianum is having strong phytotoxic activity and from the Table 2 it can be concluded that the activity was dose dependent i.e. the phytotoxic activity increased by increasing the dose of extract. The highest phytotoxic activity, shown by TSME (95\%) and HF (96\%) fraction at the concentration of $1000 \mu \mathrm{g} / \mathrm{ml}$, disclosed that these plant samples are rich in active moieties, responsible for the phytotoxic action. Table 2 revealed that the plant extracts of T. stocksianum could be an excellent source of natural herbicides. Based on the present literature and experimental verification it is worthwhile to be noticed that potentially $T$. stocksianum may be a best source of economical and efficient anticancer and natural herbicides. Owing to this probable paramount activity the different fractions rich in active principles and crude saponins should be further subjected to bioassay guided isolation in ordered to get novel, effective, economical and safe moieties for the rational management of carcinoma and weeds eradication.

\section{Conclusion}

Preliminary phytochemical screening indicated the presence of saponins along with other secondary metabolites. The crude saponins, the methanolic extract and resultant subfractions have demonstrated outstanding cytotoxic activity. Furthermore the methanolic extract and resultant subfractions have also displayed remarkable potential except CS and AF, in phytotoxicity assay. On the basis of our results we could aspect that the extracts, particularly the crude saponins could play a major role in the treatment of the current challenging disease like cancer and the n-hexane subfraction of $T$. stocksianum as herbicide. Therefore CS and HF need further scientific investigation to isolate bioactive compounds for the rational and effective use as an anticancer and natural herbicide.

\section{Methods}

Plant material

T. stocksianum was collected in the month of August 2012, from Marghuzar valley of District Swat, in the province of Khyber Pakhtunkhwa (KPK), Pakistan. Plant was identified by Professor Dr. Nasrullah Department of Botany University of Malakand Chakdara Dir, Khyber Pakhtunkhwa, Pakistan. A voucher specimen (H.UOM. BG.199b) has been deposited in the Herbarium of the same Department for future reference.

\section{Chemicals}

Methanol, $n$-hexane, chloroform, ethyl acetate (analytical grad) were purchased from Merck, Pakistan. While Paraquat and Etoposide both were procured from Sigma Aldrich having $98 \%$ purity.

\section{Extraction}

Plant was cleared, washed with tape water to remove dirt and was cut into small pieces. It was dried in shade, pulverized to coarse powder and was stored in polyethylene bags for future use. About $500 \mathrm{~g}$ was soaked for one week in methanol (80\%). The methanolic extract was passed through nylon cloth and then filtered 
through Whattman's No 1 filter paper. The extract was concentrated under reduced pressure using rotary evaporator at controlled temperature $\left(40-45^{\circ} \mathrm{C}\right)$. The percent yield of the extract was $6.2 \%(31 \mathrm{~g})$ [29].

\section{Fractionation}

The methanolic extract ( $31 \mathrm{~g}$ ) was fractionated with different organic solvents. The extract was transferred to 1.0 liter separating funnel and was suspended in about $500 \mathrm{ml}$ distilled water. The aqueous extract was partitioned with an equal volume $(500 \mathrm{ml})$ of $n$-hexane, chloroform and ethyl acetate which yielded about $4 \mathrm{~g} n$-hexane, $6 \mathrm{~g}$ chloroform, $5 \mathrm{~g}$ ethyl acetate and $12 \mathrm{~g}$ of aqueous fractions respectively [30].

\section{Extraction of crude saponins}

Crude saponins (CS) from T. stocksianum were extracted by heating the powdered sample $(20 \mathrm{~g})$ for $4 \mathrm{~h}$ at $55^{\circ} \mathrm{C}$ with $100 \mathrm{ml}$ of ethanol $(20 \%)$. The extract was filtered and residue was re-extracted with $200 \mathrm{ml}$ of ethanol (20\%). The extract was concentrated on water bath till the volume reduced to $40 \mathrm{ml}$, which was mixed with $20 \mathrm{ml}$ diethyl ether in a separating funnel. The mixture was vigorously shacked and then the separating funnel was fixed in a stand till the development of aqueous and diethyl layer. Aqueous portion was collected while the diethyl ether portion was discarded. To the aqueous layer $n$-butanol $(60 \mathrm{ml})$ was added and properly mixed by vigorous shaking. The $n$-butanol extract was treated with $10 \mathrm{ml}$ of $5 \% \mathrm{NaCl}$ solution. The resultant solution was concentrated on a water bath and the cured saponins were dried in an oven [31].

\section{Brine shrimp lethality bioassay}

Stock solution of crude saponins of $T$. stocksianum, methanolic extract and its subsequent fractions were prepared by dissolving $20 \mathrm{mg}$ of the extracts in $2 \mathrm{ml}$ of methanol. Then 10, 100, and $1000 \mathrm{ppm}$ concentrations were prepared by taking 5,50 , and $500 \mu \mathrm{l}$ respectively from the stock solution in three separate vials. The solvent (methanol) from each vial was evaporated at room temperature and 10 shrimp's nauplii were transferred to each vial with the help of dropper. In each vial $5 \mathrm{ml}$ of simulated sea water (sea salt $38 \mathrm{~g} / \mathrm{l}$ of distilled water, $\mathrm{pH}$ 7.4) was added. The negative control vials contained 10 shrimps and $5 \mathrm{ml}$ of sea water. Each dilution was prepared in triplicate. All the vials were incubated at $25-27^{\circ} \mathrm{C}$ under illumination and the survivor were counted after $24 \mathrm{~h}$ [32]. Etoposied was used as a positive control. Percent mortality was determined using the following formula;

$$
\% \text { mortality }=\frac{\text { Number of dead nauplii }}{\text { Initial number of live nauplii }} \times 100
$$

\section{Phytotoxic activity}

In-vitro phytotoxic activity of the various dilutions of crude saponins of T. stocksianum, methanolic extract and its sub-fractions were conducted against Lemna minor. Media was prepared by dissolving various inorganic components in $100 \mathrm{ml}$ of distilled water and $\mathrm{pH}$ was adjusted to $6.0-7.0$ by adding $\mathrm{KOH}$ solution. Media was sterilized at $121^{\circ} \mathrm{C}, 15 \mathrm{psi}$ for $15 \mathrm{~min}$ in autoclave. Stock solution was prepared by dissolving $10 \mathrm{mg}$ of the extract in $1 \mathrm{ml}$ of ethanol. Three sets of three different concentrations (10, 100 and $1000 \mu \mathrm{l}$ ) were prepared in flasks from the stock solution. The solvent was evaporated from the flask in aseptic environment. To each flask $20 \mathrm{ml}$ of the presterilized medium and 10 plants each having a rosette of three fronds, was added. Two other flasks were prepared containing solvent and standard phytotoxic drug (Paraquat), served as negative and positive control respectively. Afterwards, the flasks were properly plugged with cotton and were transferred to growth cabinet for seven days. On the 7th day each flask was observed and the number of fronds was counted. The percent growth inhibition was analyzed with reference to the negative control [33].

\section{Competing interests}

The authors declare that they have no competing interests.

\section{Authors' contributions}

SMMS carried out the experimental work and manuscript writing, AS supervised the experimental work and drafting the manuscript, while SMHS and SK helped in literature survey. All authors read and approved the final manuscript.

\section{Acknowledgements}

The authors are grateful to Department of Pharmacy, University of Malakand, Khyber Pakhtunkhwa, Pakistan to provide facility to conclude this research study.

\section{Funding}

This research study has been financed by the authors and has received no financial support from any other source.

\section{Author details}

${ }^{1}$ Department of Pharmacy, University of Malakand, Chakdara, Dir, Pakistan. ${ }^{2}$ Department of Pharmacy, Sarhad University of Science and Information Technology, Peshawar, KPK, Pakistan.

Received: 21 July 2014 Accepted: 24 November 2014 Published: 4 December 2014

\section{References}

1. Rates SMK: Plants as source of drugs. Toxicon 2001, 39(5):603-613.

2. Nakajima T: Gastric cancer treatment guidelines in Japan. Gastric Cancer 2002, 5(1):1-5

3. Wheeler WB: Role of research and regulation in 50 years of pest management in agriculture prepared for the 50th anniversary of the Journal of Agricultural and Food Chemistry. J Agric Food Chem 2002, 50(15):4151-4155.

4. Jastorff B, Störmann R, Ranke J, Mölter K, Stock F, Oberheitmann B, Hoffmann W, Hoffmann J, Nüchter M, Ondruschka B: How hazardous are ionic liquids? 
Structure-activity relationships and biological testing as important elements for sustainability evaluation. Green Chem 2003, 5(2):136-142.

5. Odebiyi O, Sofowora E: Antimicrobial alkaloids from a Nigerian chewing stick (Fagara zanthoxyloides). Planta Med 1979, 36(07):204-207.

6. Pietta P-G: Flavonoids as antioxidants. J Nat Prod 2000, 63(7):1035-1042.

7. Vinson JA, Su X, Zubik L, Bose P: Phenol antioxidant quantity and quality in foods: fruits. J Agric Food Chem 2001, 49(11):5315-5321.

8. Yan L, Zhang Y, Gao W, Man S, Wang Y: In vitro and in vivo anticancer activity of steroid saponins of Paris polyphylla var. yunnanensis. Exp Oncol 2009, 31(1):27-32.

9. Xi M, Hai C, Tang H, Chen M, Fang K, Liang X: Antioxidant and antiglycation properties of total saponins extracted from traditional Chinese medicine used to treat diabetes mellitus. Phytother Res 2008, 22(2):228-237.

10. De Geyter E, Lambert E, Geelen D, Smagghe G: Novel advances with plant saponins as natural insecticides to control pest insects. Pest Technol 2007, 1(2):96-105.

11. Wang G-X, Han J, Zhao L-W, Jiang D-X, Liu Y-T, Liu X-L: Anthelmintic activity of steroidal saponins from Paris polyphylla. Phytomedicine 2010, 17(14):1102-1105.

12. Zia-UI-Haq M, Riaz M, De Feo V, Jaafar HZ, Moga M: Rubus fruticosus L.: constituents, biological activities and health related uses. Molecules 2014, 19(8):10998-11029.

13. Cragg GM, Newman DJ, Snader KM: Natural products in drug discovery and development. J Nat Prod 1997, 60(1):52-60.

14. Vyvyan JR: Allelochemicals as leads for new herbicides and agrochemicals. Tetrahedron 2002, 58(9):1631-1646.

15. Almeida R, Navarro D, Barbosa-Filho J: Plants with central analgesic activity. Phytomedicine 2001, 8(4):310-322.

16. Naghibi F, Mosaddegh M, Mohammadi Motamed S, Ghorbani A: Labiatae family in folk medicine in Iran: from ethnobotany to pharmacology. Iranian J Pharm Res 2010, 2:63-79.

17. Mannan A, Inayatullah S, Akhtar MZ, Qayyum M, Mirza B: Biological evaluation of wild thyme (Thymus serpyllum). Pharm Biol 2009, 47(7):628-633.

18. Muthee J, Gakuya D, Mbaria J, Kareru P, Mulei CM, Njonge F: Ethnobotanical study of anthelmintic and other medicinal plants traditionally used in Loitoktok district of Kenya. J Ethnopharmacol 2011, 135(1):15-21.

19. Ahmad B, Mukarram Shah S, Khan H, Hassan Shah S: Enzyme inhibition activities of Teucrium royleanum. J Enzyme Inhib Med Chem 2007, 22(6):730-732.

20. Ahmad B, Mukaram Shah S, Bashir S, Begum H: Antibacterial and antifungal activities of Teucrium royleanum (Labiatea). J Enzyme Inhib Med Chem 2008, 23(1):136-139.

21. Rahim G, Qureshi R, Gulfraz M, Arshad M, Rahim S: Preliminary phytochemical screening and ethnomedicinal uses of Teucrium stocksianum from Malakand Division. J Med Plants Res 2012, 6(5):704-707.

22. Ahmad N, Anwar S, Fazal H, Abbasi BH: Medicinal plants used in indigenous herapy by people of Madyan Valley in district Swat, Pakistan. Int J Med Aromat Plants 2013, 3(1):47-54.

23. I labal I, Hamayun M: Studies on the traditional uses of plants of Malam Jabba valley, District Swat, Pakistan. Ethnobot Leaflets 2004, 2004(1):15.

24. Shah SMM, Ullah F, Shah SMH, Zahoor M, Sadiq A: Analysis of chemical constituents and antinociceptive potential of essential oil of Teucrium stocksianum bioss collected from the North West of Pakistan. BMC Complement Altern Med 2012, 12(1):244.

25. Cragg GM, Newman DJ: Plants as a source of anti-cancer agents. J Ethnopharmacol 2005, 100(1):72-79.

26. Srivastava V, Negi AS, Kumar J, Gupta M, Khanuja SP: Plant-based anticancer molecules: a chemical and biological profile of some important leads. Bioorg Med Chem 2005, 13(21):5892-5908.

27. Kerwin S: Soy saponins and the anticancer effects of soybeans and soy-based foods. Curr Med Chem-Anti-Cancer Agents 2004, 4(3):263-272.

28. Chung I-M, Miller DA: Natural herbicide potential of alfalfa residue on selected weed species. Agron J 1995, 87(5):920-925.

29. Shah SM, Sadiq A, Ullah F: Antioxidant, total phenolic contents and antinociceptive potential of Teucrium stocksianum methanolic extract in different animal models. BMC Complement Altern Med 2014, 14(1):181.

30. Ayaz M, Junaid M, Ahmed J, Ullah F, Sadiq A, Ahmad S, Imran M: Phenolic contents, antioxidant and anticholinesterase potentials of crude extract, subsequent fractions and crude saponins from Polygonum hydropiper $\mathrm{L}$. BMC Complement Altern Med 2014, 14(1):145.

31. Zeb A, Sadiq A, Ullah F, Ahmad S, Ayaz M: Phytochemical and toxicological investigations of crude methanolic extracts, subsequent fractions and crude saponins of Isodon rugosus. Biol Res 2014, 47(1):57.
32. Meyer B, Ferrigni N, Putnam J, Jacobsen L, Nichols DE, McLaughlin J: Brine shrimp: a convenient general bioassay for active plant constituents. Planta Med 1982, 45(05):31-34.

33. Saeed M, Khan H, Khan MA, Simjee SU, Muhammad N, Khan SA: Phytotoxic, insecticidal and leishmanicidal activities of aerial parts of Polygonatum verticillatum. Afr J Biotechnol 2010, 9(8).

doi:10.1186/0717-6287-47-65

Cite this article as: Shah et al:: Extraction of saponins and toxicological profile of Teucrium stocksianum boiss extracts collected from District Swat, Pakistan. Biological Research 2014 47:65.

\section{Submit your next manuscript to BioMed Central and take full advantage of:}

- Convenient online submission

- Thorough peer review

- No space constraints or color figure charges

- Immediate publication on acceptance

- Inclusion in PubMed, CAS, Scopus and Google Scholar

- Research which is freely available for redistribution

C BioMed Central 